\title{
Magnitude of bud blight disease of tomato caused by Peanut bud necrosis virus (PBNV) in Northern Eastern Karnataka
}

\author{
H.D. Vinaykumar ${ }^{1}$, M.R. Govindappa ${ }^{1 *}$, D.S. Aswathanarayana ${ }^{2}$ and M.B. Patil ${ }^{3}$ \\ ${ }^{1}$ Department of Plant Pathology, GKVK, University of Agricultural Sciences, Bengaluru-560065 (Karnataka), \\ INDIA \\ ${ }^{2}$ Department of Plant pathology, University of Agricultural Sciences Raichur -584104 (Karnataka), INDIA \\ ${ }^{3}$ Agriculture Extension and Education centre, Koppal -584104 (Karnataka), INDIA \\ *Corresponding author. E-mail: mrgpathology1@gmail.com
}

Received: March 11, 2017; Revised received: July 31, 2017; Accepted: February 5, 2018

\begin{abstract}
The present study on magnitude and spatial distribution of bud blight disease of tomato caused by Peanut bud necrosis virus in major tomato growing area of North Eastern Karnataka through GPS approach during 2014-15, revealed that disease was found to occur at all the stages of the crop with characteristic symptoms such as necrotic rings with green or yellow hallow spots on leaves, later tip necrosis and die back. Further, presence of longitudinal brown necrotic streaks on petioles, stem and characteristic brown ring and chlorotic ring spots on green and red ripened tomatoes respectively. GPS based survey indicated that the \% disease incidence varied from location to location (spatial variation), with the mean incidence ranging from 14.52 to 62.13 per cent. Among the six districts, highest incidence of 62.13 per cent was recorded in Kalaburgi district followed by Raichur, Bidar, Yadgir and Koppal with $60.35,57.96,45.68$ and 37.13 per cent incidence, respectively and the least disease incidence of 14.52 per cent was recorded in Ballari district. The GPS maps plotted based on PDI scale (0-4) represents high risk areas of the disease in North Eastern Karnataka and higher magnitude of disease was recorded in many of the location surveyed were the tomato fields surrounded by alternate hosts of PBNV. The study signifies PBNV diagnostic symptoms and its prevalence in North Eastern Karnataka.
\end{abstract}

Keywords: Bud blight disease, GPS survey, Peanut bud necrosis virus, Thrips Tomato

\section{INTRODUCTION}

India is the world's second largest producer of vegetables with an annual production of 100405 ('000 T) from 7256 ('000 ha) (FAO, 2013). A variety of vegetables are grown under field conditions and protected cultivation in the diverse agro climatic zones of the country making it possible to grow almost all varieties of fresh vegetables year-round to meet the increased demand for dietary requirements of vegetables in both rural and urban areas. Among the different vegetables tomato is one of economically important vegetable crop which is significantly contributing to Indian agriculture export. In India tomato is grown in an area of about 905.5 ('000 ha) with the production of 19103.99 ('000 T) with an average yield of 20.8 ( $\mathrm{t} / \mathrm{ha}$ ) (Anon., 2014) and is majorly grown in the states of Orissa, Bihar, Karnataka, Andhra Pradesh, Maharashtra, Madhya Pradesh, and Tamil Nadu.

Though, the area under tomato cultivation is high, the productivity (20 tones/ha) is low, due to various yield limiting biotic factors like insect pests and diseases. Among the diseases caused by fungi and bacteria, it is also affected by large number of viral diseases (Anon.,
1983). Tomato is reported to be susceptible to over 40 viruses belonging to Alfamo, Luteo, Carla, Cucumo, Gemini, Poty, Illar, Nepo, Tombus, Tobamo and Tospovirus groups (Allen and Gibbs, 1990). Among several viral diseases of tomato, leaf curl and tospoviruses are very predominant ones. The incidence of tospoviruses in vegetable crops is increasing year by year and more so in tomato (Krishna Reddy et al., 1997).

Peanut bud necrosis virus (PBNV) is the major constrain for the successful cultivation of horticulture and agriculture crop throughout the world. The severity and incidence of bud blight disease of tomato caused by PBNV is being increasing in the recent year in Karnataka on tomato (Manjunatha et al. 2010; Ambika, 2011). Besides, several reviews indicated the occurrence of Peanut bud necrosis virus incidence on wide host crops viz., Brinjal (Mandal et al., 2012), Chilli (Krishna Reddy et al., 2008) Groundnut (Mukund, 1996; Gupta and Lokesh Kumar Shukla, 2011; Gopal et al., 2011), Onion and Green gram,( Prasada Rao et al., 2003; Manoj Kumar et al., 2013 ; Bhat et al., 2001 ; Ho Xuan Thien et al., 2003). But till data, no literature is available on GPS based distribution and 
intensity of bud blight disease of tomato in potential crop growing areas of Northern Eastern Karnataka, spatial variability of disease have not been studied. Therefore, the present study was undertaken to investigate spatial distribution of bud blight disease on tomato in Northern Eastern Karnataka through global positioning system and field diagnostic symptoms for understanding the disease prevalence.

\section{MATERIALS AND METHODS}

A roving survey was carried out to know the magnitude and spatial distribution of Peanut bud necrosis virus (PBNV) disease of tomato in tomato growing districts of North Eastern Karnataka which included Ballari, Bidar, Kalaburgi, Koppal, Raichur and Yadgir during Kharif 2014. The methods for assessing the disease distribution, from each district, two taluks were selected and from each taluk two villages and in each village two locations of 100 sq. meter area were selected as sampling point. Each sampling point was geo referenced in the Univer-sal Transverse Mercator (UTM) co-ordinate system with a Global Positioning System (GPS). By using global positioning system (GPS) (Trimble MAK - Geo XH), the co-ordinates (latitudes and longitudes) were collected to map the spatial variation of bud necrosis disease of tomato. In each sampling point, to understand the magnitude of disease was assessed based on per cent disease incidence (PDI) by using the formula mentioned below. Further, the incidence of the disease from each location of the above districts was categorised based on disease rating scale $0-4(0=$ No incidence; $1=1-24.9 \%$ PDI; $2=25-49.9 \%$ PDI; $3=50-74.9 \%$ PDI and $4=>75 \%$ PDI) for the convenience to develop GIS maps to understand the spatial variation of disease.

PDI $(\%)=$ Number of diseased plants / Total number of plants x 100

GPS data import: The collected sample locations from GPS were imported using path finder software. Since the projection system of selected locations were pre-defined in the GPS, the imported sample points were found within the respective village administrative boundary (having similar projection and datum i.e., UTM, WGS 84), when imported in the GIS environment.

Data attachment and mapping: The field observations on bud necrosis virus disease distribution and severity were fed in excel sheet with proper labelling for each observation made. The unique identity (id) was added and the physical $i d$ was created along with the sample locations imported in the Arc GIS environment. Further, the collected field data were attached to the respective GPS location points using unique id 121 relationships in Arc GIS 2010. The disease incidence of bud necrosis virus disease of tomato was displayed through unique symbology to understand the spatial distribution of the disease. The maps of spatial distribution of bud necrosis virus disease in surveyed dis- tricts viz. Raichur, Ballari, Koppal, Yadagri, Bidar and Kalaburgi are given in the Fig. 1. The Differential Global Positioning System (DGPS) used in this study is the latest version (GeoXH) from Trimble, which is enabled to receive the more accurate satellite signals from Global Navigation Satellite System (GNSS) which will give more accurate location reading.

Computer software: ArcGIS 10 software from Department of Pathology, College of Agriculture, Raichur was used for the processing and analysis of the data. In addition to this, symptoms of the PBNV disease on tomato were also observed on different growth stage of the crop during the survey. The results pertaining on disease prevalence through GPS survey are presented hereunder.

\section{RESULTS AND DISCUSSION}

Investigation regarding GPS based spatial distribution of bud blight disease of tomato caused by PBNV in North Eastern Karnataka revealed that disease was found to occur at all the stages of the crop. Diseased tomato plants in the surveyed fields exhibited characteristic symptoms such as necrotic rings with green or yellow hallow spots on leaves, tip necrosis and die back on growing bud is more prominent. Further the presence of longitudinal brown necrotic streaks on the petioles, stem and it was also noticed that early infection in plants resulted in stunted growth, wilting and death of the plants, later infected plants set fruits with a characteristic brown ring and chlorotic ring spots on green and red ripened tomatoes respectively (Fig 1). The vector of the disease, viz., thrips were invariably found in every infected field surveyed. Similar type of PBND symptoms on tomato was observed by several workers in India (Todd et al., 1975; Prasad Rao et al., 1980; Sastry, 1982; Hemalatha, 1999; Anjaneya Reddy et al., 2008; Manjunatha et al., 2010 and Ambika, 2011). The GPS based survey for occurrence and magnitude of PBND revealed that the ubiquitous presence of disease in all the tomato growing area with the mean incidence ranging from 14.52 to 62.13 per cent. Among the six districts, highest incidence of 62.13 per cent was recorded in Kalaburgi district followed by Raichur, Bidar, Yadgir and Koppal with 60.35, 57.96, 45.68 and 37.13 per cent incidence, respectively and the least disease incidence of 14.25 per cent was recorded in Ballari district (Table 1).

Further, GPS maps also helps in indicating the spatial variability (Location to location) of bud blight disease of tomato across the surveyed areas and results are represented in GIS maps. Far instances, In Kalaburgi district incidence of bud blight disease of tomato reveals that the highest incidence of 68.06 per cent in Kadaganchi village followed by Chinchansur (66.78\%) village of Aland taluk (Table 1; Fig. 2). Survey from Koppal district indicated, highest (45.39\%) in Lebigeri village of Koppal taluk and least incidence (31.4\%) 
H.D. Vinaykumar et al. / J. Appl. \& Nat. Sci. 10(1): 301 - 306 (2018)

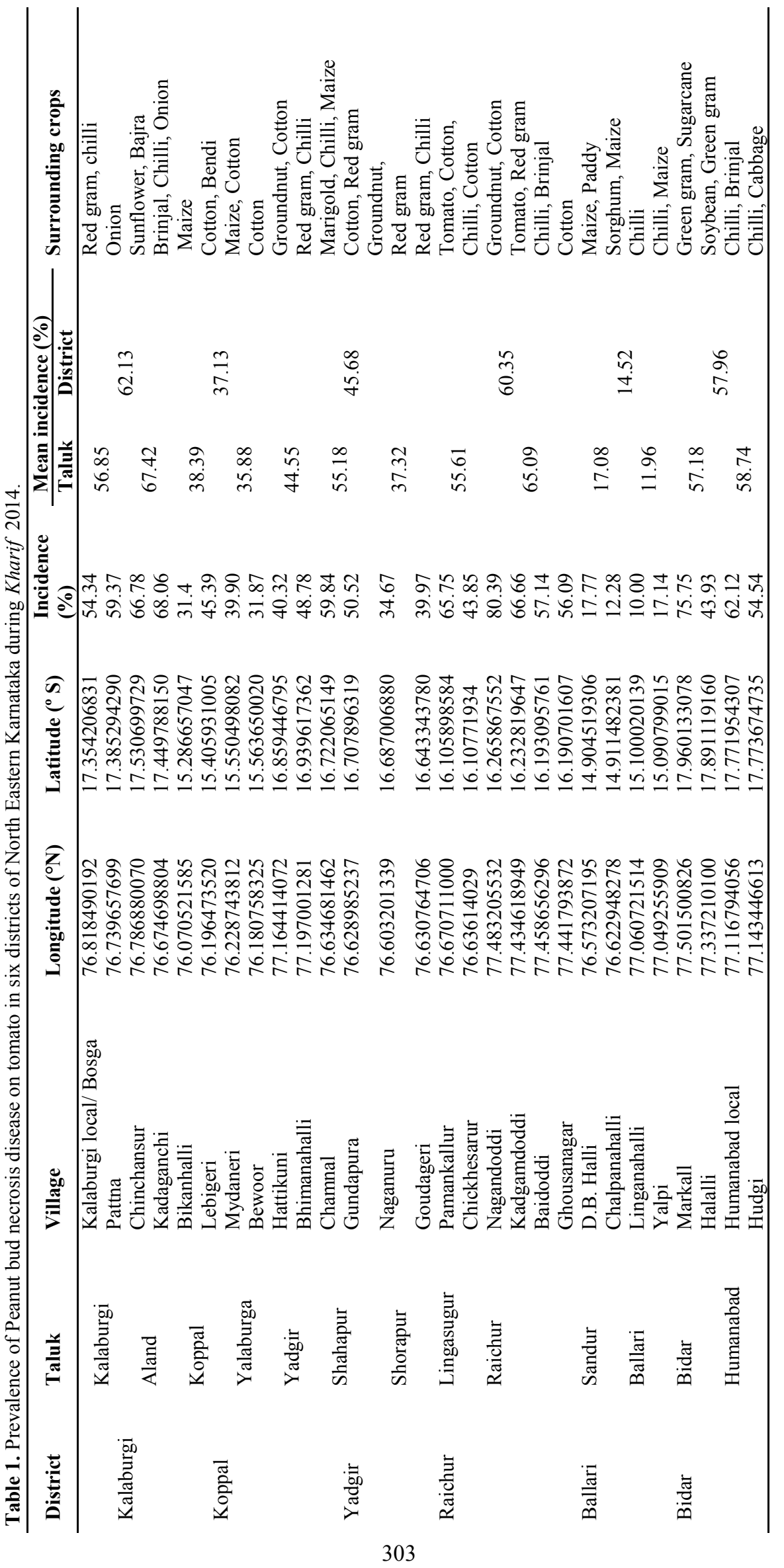


H.D. Vinaykumar et al. / J. Appl. \& Nat. Sci. 10(1): 301 - 306 (2018)

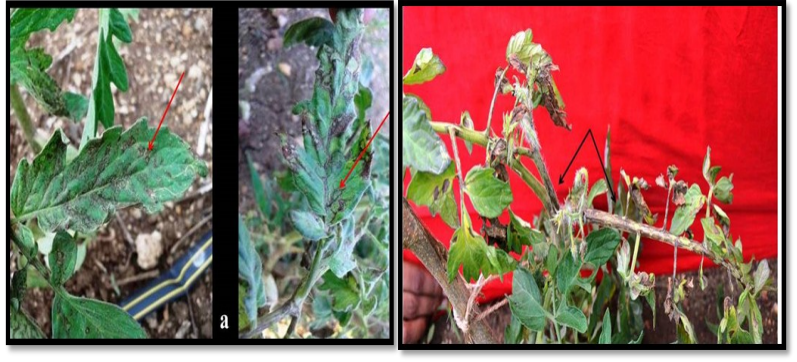

a. Necrotic rings with yellow b. Longitudinal brown hallow spots on the leaves. streaks on petiole and stem region
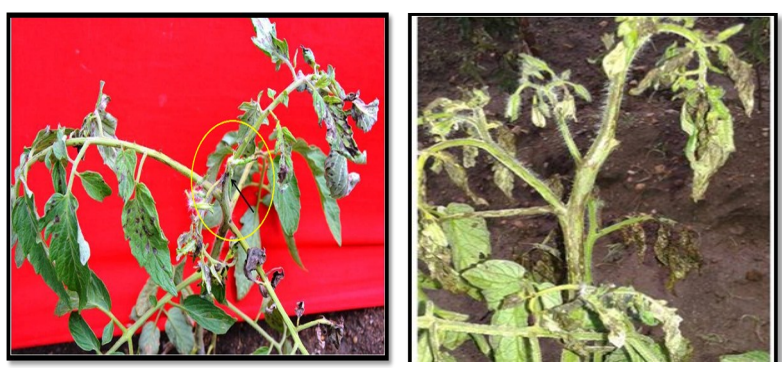

c. Terminal bud necrosis.

\section{d. Drying of plant}

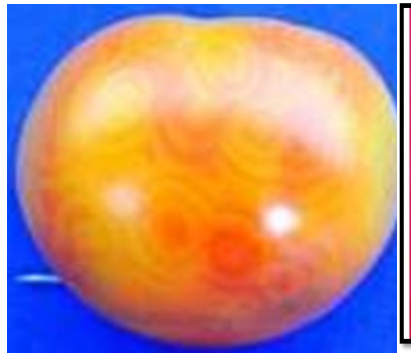

e. Chlorotic rings on ripe fruit

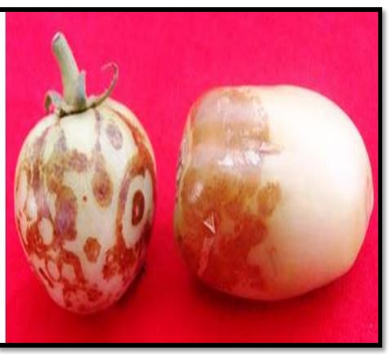

f. Brown rings on immature fruit

Fig. 1. Field symptoms of bud blight disease of tomato caused by PBNV.

was in Bikanhalli village of Koppal taluk (Table 1; Fig. 3). While in Yadgir district, peak disease incidence of 59.84 per cent was noticed in Chamnal village of Shahapur taluk, and lowest disease incidence of 34.67 per cent was noticed in Naganur village of Shorapur taluk (Table 1; Fig. 4). The survey in Raichur district indicated, highest disease incidence $(80.39 \%)$ was noticed in Nagandoddi village followed by Kadgamdoddi village ( $66.6 \%)$ of Raichur taluk, and lowest disease incidence was noticed in Chickhesarur (43.85\%) village of Lingsugur taluk during (Table 1; Fig. 5). In Ballari district, bud blight disease incidence was highest in D. B. Halli (17.77\%) village of Sandur taluk however lowest disease incidence was noticed in Linganahalli (10\%) village of Ballari taluk (Table 1; Fig. 6). In Bidar district, highest disease incidence of 75.75 per cent was noticed in Markal village of Bidar taluk and lowest disease incidence $(43.9 \%)$ was noticed in Halalli (Table 1; Fig.7). The survey data revealed the ubiquitous presence of bud blight disease

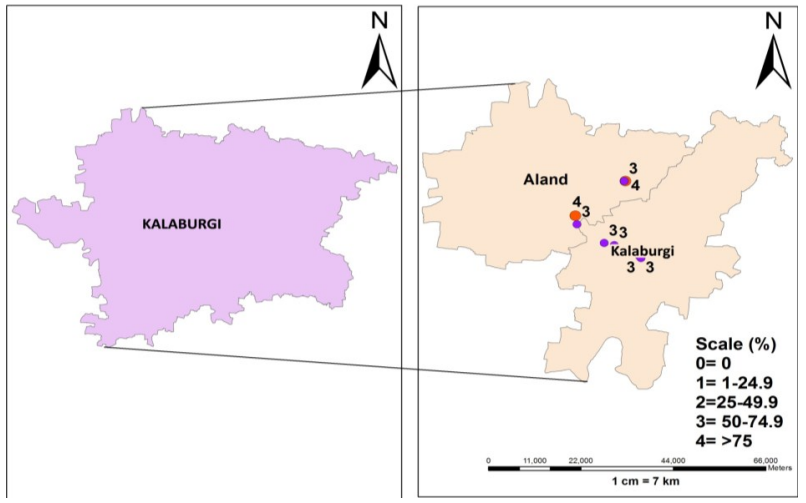

Fig. 2. Spatial variability of $P B N V$ disease incidence on tomato in Kalaburgi district of Karnataka during Kharif 2014.

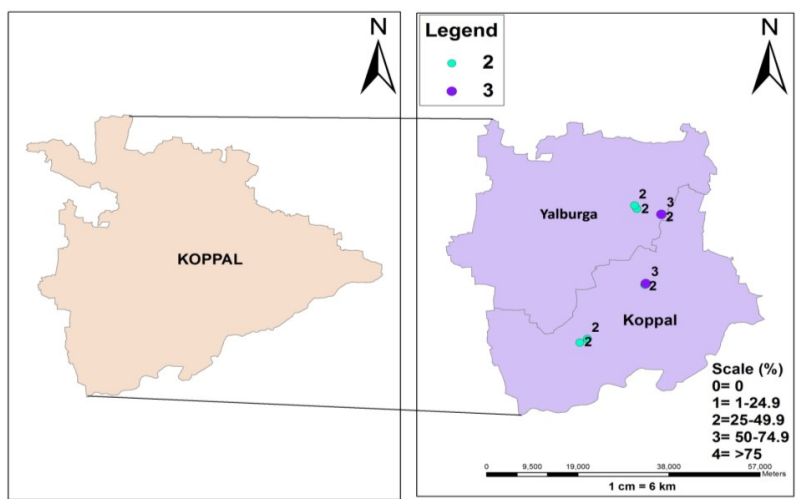

Fig. 3. Spatial variability of $P B N V$ disease incidence on tomato in Koppal district of Karnataka during Kharif 2014.

on tomato in North- Eastern region of Karnataka, the per cent disease incidence varied from location to location and severity of disease varied with stage of the crop.

The difference incidence of disease in surveyed areas might be due to the variation in the source of virus inoculum, vector population, climatic conditions and the susceptibility of tomato genotypes. Highest disease incidence on tomato fields in surveyed areas were found surrounded by the alternate host crop such as Brinjal, Chilli and Groundnut which might have served as source of inoculum. To support this, several reviews indicated the occurrence of virus incidence on Brinjal (Mandal et al., 2012), Chilli (Krishna Reddy et al., 2008) Groundnut (Mukund, 1996; Gupta and Lokesh Kumar Shukla, 2011; Gopal et al., 2011), Onion and Green gram,( Prasada Rao et al., 2003; Manoj Kumar et al., 2013 ; Bhat et al., 2001 ; Ho Xuan Thien et al., 2003). Beside this, the other probable reason for higher incidence due to sequential and mono cropping of tomato may also have positive influence on the occurrence of the disease. The locations were lower necrosis disease incidence on tomato fields were surrounded by crops such as maize and sorghum. These crops are reported as non-host of virus inoculum and also served as biological barrier to restrict the movement of thrips vector (Manoj Kumar et al., 2013).Further, diagram- 
H.D. Vinaykumar et al. / J. Appl. \& Nat. Sci. 10(1): 301 - 306 (2018)

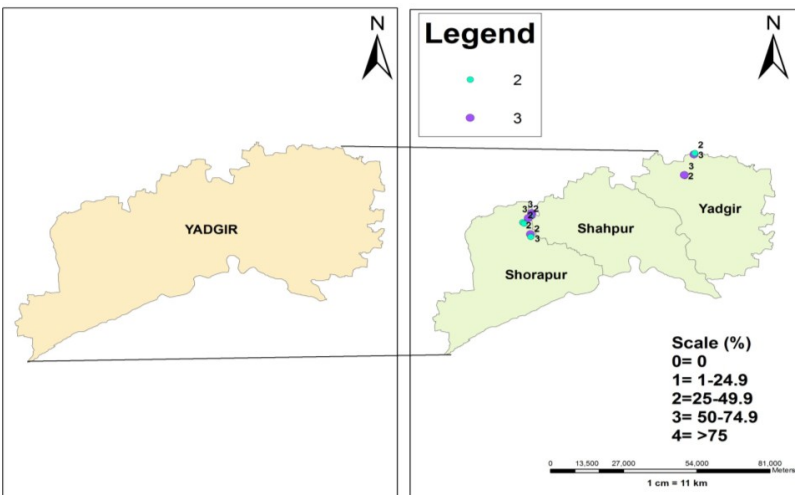

Fig. 4. Spatial variability of $P B N V$ disease incidence on tomato in Yadgir district of Karnataka during Kharif 2014 -15 .

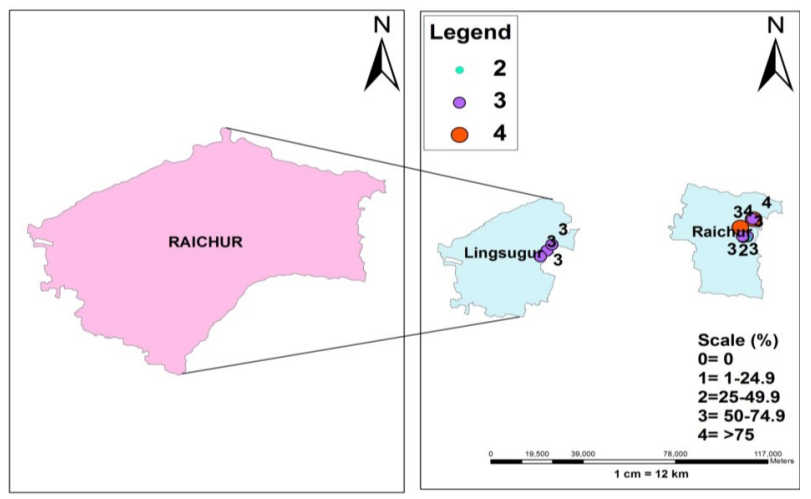

Fig. 5. Spatial variability of $P B N V$ disease incidence on tomato in Raichur district of Karnataka during Kharif 2014.

matic representation of virus incidence through map showed that different colour legends represents high and low risk area with per cent disease incidence. The variability of disease is likely due to the fact that varied environmental and biotic factors such as sources of disease inoculum and the movement of insect vector and also the host susceptibility. Similarly, earlier survey for PBND on different crops indicated, an incidence of 25.40 per cent on groundnut in Karnataka (Mukund, 1996) while seventy per cent incidence on groundnut in New Delhi (Gupta and Lokesh Kumar Shukla, 2011), 33 per cent on tomato in North India (Singh and Tripati, 1991), 19-34 per cent on tomato in Karnataka, Kerala, Maharashtra, Tamilnadu and Uttar Pradesh (Raja and Jain 2006), 56.14-94.4 per cent on tomato in Karnataka (Manjunatha et al. 2010; Ambika., 2011), 30.6 per cent on tomato in Tamilnadu (Thiribhuvanamala et al., 2013), 33.96 per cent on mungbean in Andhra Pradesh (Prasada Rao et al., 2003), 70 per cent on mungbean in New Delhi (Ho Xuan Thien et al., 2003) and 20 per cent on chilli (Krishna Reddy et al., 2008).

\section{Conclusion}

The present investigation on peanut bud necrosis disease of tomato revealed that the disease was found to

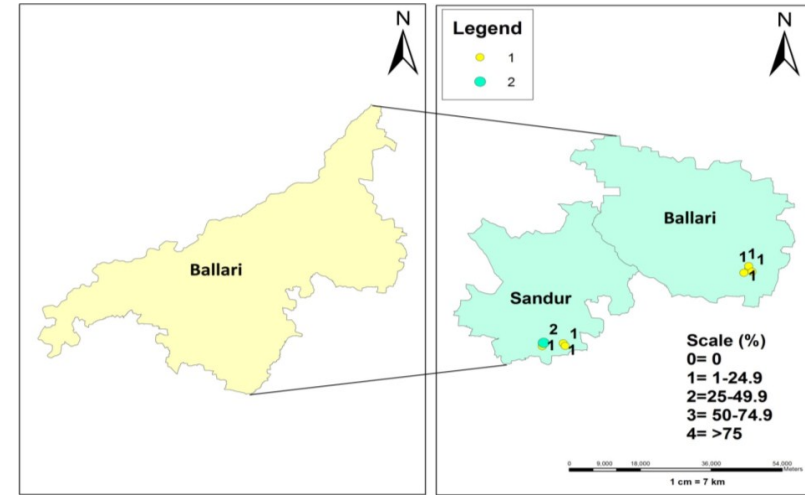

Fig. 6. Spatial variability of $P B N V$ disease incidence on tomato in Ballari district of Karnataka during Kharif 2014.

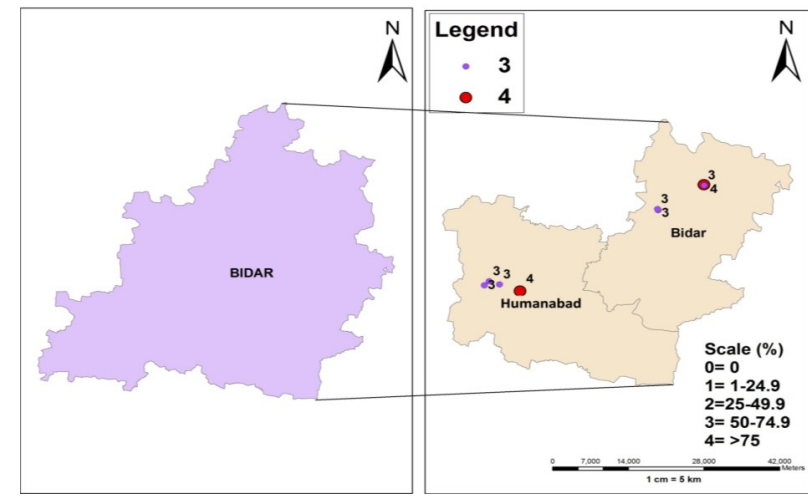

Fig. 7. Spatial variability of $P B N V$ disease incidence on tomato in Bidar district of Karnataka during Kharif 2014.

occur both in vegetative and reproductive stages of the crop. GPS based survey indicated that per cent disease incidence varied from location to location (spatial variation) and however, Kalaburgi, Bidar, Raichur and Yadgir districts of North Eastern Karnataka were found high risk areas of the disease for tomato cultivation, where tomato fields were surround by alternate crops such as legumes, chillies and groundnut hosts.

\section{ACKNOWLEDGEMENTS}

This research is part of M.Sc (Agri.) dissertation and authors are very much thankful to Department of Plant Pathology UAS, Raichur, for providing global positioning system (GPS) (Trimble MAK - Geo XH) for recoding the co-ordinates (latitudes and longitudes) and Arc GIS 10 software for development of the GPS maps.

\section{REFERENCES}

Allen, B. and Gibbs, K. C. (1990). Viruses of tropical plants. CAB International, Oxon, UK. pp. 707.

Ambika, D. S. (2011), Monitoring and management of groundnut bud necrosis virus in tomato. Ph.D. Thesis, Univ. Agric. Sci., Bangalore (India).

Anjaneya Reddy, B., Krishna Reddy, M., Salil Jalali, Patil, M. S. and Usharani, T. R. (2008). Detection of a 
tospovirus-infecting tomato (Solanum lycopersicon), Indian J. Virol., 19(1): 32-35.

Anonymous. (1983). Pest control in tropical tomatoes, Centre for overseas pest research, London, p 130.

Anonymous. (2014). http://agricoop.nic.in/agristatistics.htm.

Bhat, A. I., Jain, R. K., Varma, A., Naresh Chandra and Lal, S. K. (2001). Tospovirus infecting grain legumes in Delhi-their identification by serology and nucleic acid hybridization. Indian Phytopath., 54(1): 112-116.

FAO Statistical Year book 2013

Gopal, K., Muniyappa, V. and Jagadeeshwar, R. (2011). Management of peanut bud necrosis disease in groundnut by botanical pesticides. Arch. Phytopathol. Pl. Prot., 44 (13): 1233-1237.

Gupta, U. P. and Lokesh Kumar Shukla. (2011)., Ground nut bud necrosis disease caused by a strain of ground nut bud necrosis virus. Indian J. Res., 5: 46-50.

Hemalatha. (1999). Detection and transmission of tomato necrotic spot tospovirus (TNSV) infecting tomato (Lycopersicon esculentum Mill.). M. Sc (Agri) Thesis Uni. Agric. Sci., Bengaluru (India), 81pp.

Ho Xuan Thien, Bhat, A. I. and Jain, R.K. (2003). Mungbean necrosis disease caused by a strain of Ground nut bud necrosis virus. Omonrice, 11:110-116.

Krishna Reddy, M., Gopal, K., Akelavani and Sigh, S. J. (1997). Immunological detection and serological comparison of tospovirus isolates using polyclonal and monoclonal antibodies. In: International conference on Integrated Plant Disease Management for Sustainable Agriculture, IPS golden jubilee, IARI, New Delhi November $10-15, \mathrm{p} 36$.

Krishna Reddy, M., Usha Rani, R., Anil Kumar, K. S., Madhavi Reddy, K. and Pappu, H. R.(2008). Capsicum chlorosis virus (Genus Tospovirus) infecting Chilli Pepper (Capsicum annuum) in India. Plant Disease, 92 (10): 1469.

Mandal, B., Jain, R. K., Krishnareddy, M., Krishna Kumar, N. K., Ravi, K. S. and Pappu, H. R. (2012), Emerging problem of tospoviruses (Bunyaviridae) and their management in Indian subcontinent. Plant. dis. J., 96(4): 468-479.
Manjunatha, L., Patil, M. S., Thimmegowda, P. R., Vijaya Mahantesha, M. R. and Nataraj, K. (2010). Survey and incidence of bud blight disease of tomato in parts of Karnataka. J. Pl. Dis. Sci., 5 (1): 102-104.

Manoj Kumar, V.,willams, P. and Roopa Lavanya, G.(2013). Eco-friendly Management of Groundnut Bud Necrosis Disease in Allahabad District of Uttar Pradesh. Indian Journal of Plant Protection, 44 (1): 85-90.

Mukund, S. K. (1996). Studies on bud necrosis virus disease of Groundnut (Arachis hypogaea) in Karnataka. Ph.D. Thesis submitted to Uni. Agric. Sci., Dharwad (India), $125 \mathrm{pp}$.

Pappu, H. R., Jones, R. A. C. and Jain, R. K. (2009). Global status of tospovirus epidemics in Diverse cropping systems: Successes achieved and challenges ahead. Virus Res, 141:219-236.

Prasada Rao, R. D. V. J., Izuna, N., Ragunathan, V. and Joshi, N. C. (1980). Occurrence of Tomato spotted wilt virus on tomato in Andhra Pradesh. Indian Phytopath., 33:436-439.

Prasada Rao, R. D. V. J., Sarath Babu, B., Sreekant, M. and Manoj Kumar, V. (2003). ELISA and infectivity assay based survey for the detection of peanut bud necrosis virus in mungbean and urdbean in Andhra Pradesh. Indian J. Pl. Prot., 31(1): 26-28.

Raja, P. and Jain, R.K. (2006). Molecular diagnosis of groundnut bud necrosis virus causing bud blight of tomato, Indian Phytopath., 59(3): 359-362.

Sastry, K.S. (1982). Occurrence of spotted wilt on tomato in Karnataka. Curr. Sci., 51pp.

Singh, B. R. and Tripathi. (1991). Loss due to leaf curl and spotted wilt diseases of tomato, Madras Agric., J., 78: 34-36.

Thiribhuvanamala, G., Murugan, M., Jayalakshimi, V., Manoranjithami, S. K., Renukadevai, P. and Rabinarani, R. (2013). Strategic approaches for the management of pea nut bud necrosis virus disease of tomato. Pest Management in Horticultural Eco-systems., 19)(1): 67-72.

Todd, J. M., Ponnaiah, S. and Subramanyam, (1975). First record of tomato spotted wilt virus from the Niligiris in India. Madras Agric., J., 525(3): 162 -163. 